\title{
STRATEGI PENINGKATAN KUALITAS KONTEN DIKLAT BERBASIS E-LEARNING PADA PUSDIKLAT ANGGARAN DAN PERBENDAHARAAN
}

\author{
The Strategy of Content Quality Improvement for E-Learning on Budget and \\ Treasury Training Center
}

\author{
Anik Juniastuti', A Faroby Falatehan², Pudji Muljono ${ }^{3}$ \\ 1 Staf Bagian Keuangan Sekretariat Badan Pendidikan dan Pelatihan Keuangan, Jakarta Selatan. \\ E-mail: anik.juniastuti@gmail.com \\ ${ }^{2}$ Staf Staff Pengajar Departemen Ekonomi Sumberdaya dan Lingkungan. Fakultas Ekonomi dan \\ Manajemen. IPB. Email : affalatehan@gmail.com \\ ${ }^{3}$ Staf Pengajar Departmen Sains Komuikasi dan Pengembangan Masyarakat, Fakultas Ekologi \\ Manusia, IPB. Email: skpm@apps.ipb.ac.id
}

\begin{abstract}
Content is an important variable in e-learning implementation. Creating the right content, will determine success in learning based on information and communication technology. The results of research in Budget and Treasury Training Center states that e-learning is no more effective than classical, due to the method of delivering inappropriate teaching materials. This research will formulate the strategy of content quality improvement for e-learning on the Budget and Treasury Training Center. First analysis of internal and external factors that determine the quality of e-learning based training content. The analysis was performed using Internal Factor Evaluation (IFE) and External Factor Evaluation (EFE) matrix. The second phase focuses on developing alternative strategies by aligning key internal and external factors. Strength Weakness Opprtunity Threat (SWOT) Analytical techniques will get some alternative strategies. Last stage is to set priority strategy using Quantitative Strategic Planning Matrix (QSPM). This research formulates the strategy of optimization of the training services by creating excellent services of e-learning. The policies were the provision of learning materials in attractive packaging, fulfillment of user needs and user friendly. These policies were outlined in three programs: designing edutainment programs, designing micro learning for learning materials, and providing LMS application of android version.
\end{abstract}

Key Words: Content Quality, IFE, EFE, SWOT, QSPM

\section{ABSTRAK}

Konten merupakan variabel penting dalam implementasi e-learning. Membuat konten yang tepat, akan menentukan keberhasilan dalam belajar menggunakan bantuan teknologi informasi dan komunikasi. Penelitian terkait e-learning di Pusdiklat Anggaran dan Perbendaharaan menyatakan bahwa diklat dengan metode e-learning tidak lebih efektif dibanding dengan metode klasikal. Hal tersebut disebabkan cara penyampaian materi dalam bentuk bahan ajar yang tidak tepat. Penelitian ini akan merumuskan strategi peningkatan kualitas konten diklat berbasis $e$ learning pada Pusdiklat Anggaran dan Perbendaharaan. Tahapan analisis yang dilakukan yaitu, pertama analisis faktor-faktor internal dan eksternal yang menentukan kualitas konten diklat berbasis e-learning. Analisis dilakukan menggunakan matriks Internal Factor Evaluation (IFE) dan External Factor Evaluation (EFE). Tahap kedua berfokus pada pembuatan strategi alternatif yang layak dengan menyelaraskan faktor internal dan eksternal kunci. Teknik analisis menggunakan metode Strength Weakness Opportunity Threat (SWOT) akan menghasilkan beberapa alternatif strategi. Tahap ketiga adalah menetapkan prioritas strategi menggunakan Quantitative Strategic Planning Matrix (QSPM). Penelitian ini merumuskan strategi optimalisasi layanan kediklatan dengan membangun layanan unggulan diklat berbasis e-learning. Kebijakan yang ditetapkan adalah penyediaan materi belajar dalam kemasan yang menarik, memenuhi kebutuhan pengguna, dan user friendly. Kebijakan dijabarkan dalam tiga program yaitu merancang program edutainment, merancang materi dalam bentuk micro learning, dan menyediakan aplikasi LMS versi android.

Kata Kunci: Kualitas Konten, IFE, EFE, SWOT, QSPM 
terdiri dari pejabat struktural Bidang Renbang pada Pusdiklat Anggaran dan Perbendaharaan, staf dan Widyaiswara yang terlibat dengan proses kegiatan pembelajaran pada diklat PBJ dengan metode e-learning. Data sekunder berupa peraturan, pedoman, laporan, kajian terdahulu dan sebagainya yang diperoleh dari Pusdiklat Anggaran dan Perbendaharaan maupun melalui media publikasi.

\section{Metode Analisis Data}

Penelitian ini menggunakan analisis IFE dan EFE untuk mengetahui kekuatan utama, kelemahan utama, peluang utama, dan ancaman utama. Menurut David dan David (2016) dalam mengidentifikasi faktor-faktor internal keterlibatan perwakilan manajer dan karyawan sangat diperlukan dalam menentukan kekuatan dan kelemahan, melalui pengumpulan, asimilasi, dan evaluasi informasi mengenai proses bisnis organisasi. Demikian juga dalam mengidentifikasi faktor-faktor eksternal keterlibatan perwakilan manajer dan karyawan sangat diperlukan dalam menentukan peluang dan ancaman yang dihadapi organisasi. Organisasi sebaiknya merespon secara ofensif atau defensif terhadap faktorfaktor ini dengan memformulasikan strategi yang dapat memanfaatkan peluang atau meminimalisasi dampak ancaman potensial. Kekuatan dan kelemahan internal bersama dengan peluang dan ancaman eksternal, serta visi dan misi yang jelas, memberikan dasar untuk membangun tujuan dan strategi. Tujuan dan strategi dibangun dengan keinginan memanfaatkan kekuatan internal dan mengatasi kelemahan.

Mengidentifikasi dan mengevaluasi strategi alternatif sebaiknya melibatkan manajer dan karyawan yang sebelumnya merumuskan visi dan misi organisasi, serta mereka yang mengidentifikasi Teknik formulasi strategi yang penting

dapat diintegrasikan dalam tiga kerangka kerja pembuatan keputusan, yaitu:

1. Tahap input yaitu formulasi kerangka kerja yang minimal terdiri atas matriks IFE, matriks EFE. Tahap ini meringkas informasi input mendasar yang dibutuhkan untuk memformulasikan strategi.

2. Tahap pencocokan, berfokus pada pembuatan strategi alternatif yang layak dengan menyelaraskan faktor internal dan eksternal kunci. Teknik tahap ini menggunakan matriks SWOT.

3. Tahap keputusan, melibatkan teknik tunggal QSPM dengan menggunakan informasi input dari tahap 1 secara obyektif mengevaluasi strategi yang diidentifikasi dalam tahap 2. QSPM mengungkapkan daya tarik relatif dari strategi alternatif dan memberikan dasar yang obyektif dalam memilih strategi tertentu.

\section{HASIL DAN PEMBAHASAN}

Lembaga diklat dituntut memberikan pelayanan kediklatan yang terbaik agar pengguna layanan merasakan kemanfaatan, sehingga diharapkan para lulusan diklat dapat menerapkan ilmunya di tempat kerjanya. Kualitas pembelajaran merupakan hal penting dalam penyelenggaraan diklat karena inti dari proses pembelajaran adalah konten pembelajaran. Konten adalah materi pelajaran yang disampaikan dalam diklat, dan pada diklat berbasis e-learning konten juga merupakan sistem aplikasi yang menjadi akses utama peserta diklat. Pusdiklat Anggaran dan Perbendaharaan sebagai penyelenggara diklat PBJ dengan metode blended learning, yaitu kombinasi e-learning dan klasikal, harus mampu menjaga dan meningkatkan kualitas konten diklat.

Menurut Chapnick dalam Oketch (2014), salah satu faktor dalam E-Learning Readiness (ELR) adalah content readiness, dimana komponen dari content readiness terdiri dari materi pembelajaran dan tujuan pembelajaran. Konten 
merupakan bagian penting dalam proses delivery materi diklat. Inti dari diklat adalah kesiapan materi yang akan diajarkan kepada peserta. Supaya materi tersebut dapat sampai kepada peserta, dapat difahami oleh peserta, maka cara penyampaian materi atau metode pembelajaran harus menjadi perhatian dalam proses penyelenggaraan diklat. Dalam e-learning sebagian atau seluruh proses pembelajaran berbantuan dengan teknologi atau sistem aplikasi. Hernawati dan Aji (2016) menyatakan bahwa konten yaitu berupa format, media dan materi dalam e-learning, yang lebih mengarah pada penyediaan aplikasi.

\section{Identifikasi Faktor-faktor Internal dan Eksternal}

Faktor-faktor yang menjadi kekuatan, kelemahan, peluang, dan ancaman terkait dengan kualitas konten diklat berbasis $e$ learning pada Pusdiklat Anggaran dan Perbendaharaan diperoleh melalui wawancara terhadap pejabat struktural, Widyaiswara, dan pelaksana. Identifikasi faktor-faktor internal dan eksternal yang menentukan kualitas konten diklat ini akan ditinjau dari sudut pandang organisasi sebagai unit obyek.

\section{A. Kekuatan (Strengths)}

1. Desain program diklat telah melalui proses validasi.

Salah satu indikator kinerja utama (IKU) dalam pengelolaan diklat adalah validasi program diklat. Target IKU ini adalah program diklat yang mendapat nilai validasi A. Tujuannya adalah untuk menjamin kelayakan program sebelum diklat diselenggarakan. Hal ini diatur dalam Keputusan Kepala BPPK Nomor KEP-006.1/PP/2011 tentang Validasi Program Diklat. Termasuk dalam lingkup penilaian validasi ini adalah ketersediaan dan kelengkapan perangkat diklat yang antara lain meliputi kurikulum, bahan ajar, fasilitator/narasumber/pengajar, dan kelas. Jadi, proses validasi merupakan upaya BPPK menjaga kualitas diklat termasuk adalah menjaga kualitas konten diklat.

2. Ketersediaan tenaga pengajar yang kompeten dengan dibuktikan melalui sertifikasi.

Narasumber/pengajar PBJ adalah seseorang yang memiliki/pemegang Sertifikasi Pelatihan untuk Pelatih Pengadaan Barang/Jasa yang diterbitkan oleh Lembaga Kebijakan Pengadaan Barang/Jasa Pemerintah (LKPP). Pusdiklat Anggaran dan Perbendaharaan mempunyai 6 Widyaiswara yang mengajar pada diklat PBJ dan semuanya telah memiliki sertifikat tersebut. Tugas Widyaiswara ini adalah mendesain program diklat $\mathrm{PBJ}$, menyusun kurikulum dan menyiapkan bahan ajar. Oleh karena itu tenaga pengajar yang kompeten akan menentukan kualitas konten diklat.

3. SDM pengelola diklat yang berkualitas. Nilai-nilai Kementerian Keuangan menjadi landasan perilaku bagi seluruh pegawainya yang meliputi integritas, profesional, sinergi, pelayanan, dan kesempurnaan. Sesuai dengan maknanya, nilai atau value merupakan bagian dari falsafah hidup yang diyakini menjadi penentu arah tindakan dan pedoman dalam bersikap dan berperilaku, dan ketika nilai-nilai ini dilakukan terus-menerus maka akan menjadi budaya. Selain itu SDM pengelola diklat juga memiliki tingkat pendidikan yang sangat memadai. Hal ini dapat dilihat dari profil pegawai di Pusdiklat Anggaran dan Perbendaharaan dengan jumlah pegawai 87 orang latar belakang tingkat pendidikan S2 sebanyak 29 orang, S1/D4 sebanyak 32 orang, D3 sebanyak 14 orang, D1 sebanyak 3 orang dan SMA sebanyak 9 orang. Sedangkan untuk tenaga keamanan dan kebersihan diangkat tenaga honorer. 
Pengelola diklat menjadi bagian yang turut berperan dalam menentukan kualitas konten diklat. Dukungan yang diberikan antara lain adalah penyediaan infrastruktur baik fisik maupun non fisik yang ditujukan untuk meningkatkan kualitas penyelenggaraan diklat. Melihat kondisi tersebut, SDM menjadi kekuatan dalam memberikan kontribusi terbaik untuk meningkatkan kualitas layanan.

4. Sarana dan prasarana yang mendukung penyelenggaraan diklat.

Keberhasilan proses pembelajaran juga harus didukung dengan ketersediaan sarana dan prasarana yang memadai. Salah satu IKU dalam pengelolaan diklat yang mengukur tingkat kepuasan peserta yaitu indeks persepsi peserta diklat terhadap proses pembelajaran. Indeks persepsi peserta diklat merupakan penilaian peserta atas kualitas pengajar, kualitas bahan ajar, kualitas metodologi pembelajaran serta ketersediaan dan kualitas sarana prasarana. Dari laporan kinerja BPPK tahun 2016 diketahui bahwa target IKU ini adalah 4 dari skala 5, dan capaian indeksnya adalah 4,36. Artinya upaya yang dilakukan oleh Pusdiklat Anggaran dan Perbendaharaan untuk mensukseskan proses belajar telah dinilai baik oleh pengguna layanan.

Hal ini juga didukung oleh adanya Keputusan Kepala BPPK Nomor KEP007.1/PP/2011 tentang Standar Sarana dan Prasarana di Lingkungan BPPK yang harus dipedomani. Terselenggaranya diklat Pengadaan Barang dan Jasa dengan metode elearning yang sudah berjalan, tidak lepas dari dukungan sarana dan prasarana yang dibutuhkan untuk hal tersebut. Sebagai contohnya adalah pembangunan learning management system yang menjadi akses utama proses pembelajaran berbasis elearning.
5. Koordinasi yang baik dengan unit teknis selaku perancang kebijakan.

Hubungan yang baik dengan unit teknis perancang kebijakan mutlak dilakukan, karena diklat-diklat yang didesain oleh Pusdiklat Anggaran dan Perbendaharaan sumbernya adalah kebijakan tersebut. Bentuk koordinasi yang telah dilakukan misalnya dalam hal desain program diklat, kerjasama tenaga ahli dalam pendidikan, bimbingan teknis, dan sebagainya. Koordinasi yang baik terkait dengan kualitas konten diklat karena dalam hal desain program diklat akan berbicara tentang kurikulum, bahan ajar, metode pembelajaran, dan sebagainya yang kesemuanya menjadi bagian dari konten diklat. Kerjasama tenaga ahli dalam pendidikan atau bimbingan teknis bertujuan untuk meningkatkan pemahaman pegawai Pusdiklat Anggaran dan Perbendaharaan terkait kebijakan teknis, dan peningkatan wawasan keilmuan dapat dimanfaatkan dalam membuat konten diklat.

B. Kelemahan (Weaknesses)

1. Penyelenggaraan diklat dengan metode e-learning belum memperoleh quality assurance dari lembaga sertifikasi.

Anggraini (2014) menyatakan bahwa manajemen mutu pembelajaran sebagai salah satu strategi manajemen mampu memberikan dampak positif dalam meningkatkan kualitas pendidikan. Pendidikan yang berkualitas tentunya didukung oleh konten yang berkualitas. Jika perencanaan kualitas pembelajaran dilakukan dengan baik, maka akan dapat memenuhi kebutuhan pelanggan. Pusdiklat Anggaran dan Perbendaharaan telah melakukan tata kelola kediklatan yang baik dengan diperolehnya sertifikasi ISO 9001:2008 untuk pengelolaan proses bisnis kediklatan. Namun standar manajemen mutu tersebut masih 
terbatas pada penyelenggaraan diklat klasikal, dan hingga saat ini belum dilakukan pengembangan manajemen mutu untuk proses diklat berbasis $e$ learning.

2. Adanya pegawai yang resisten terhadap perubahan.

Resistensi terhadap perubahan ini biasanya dikarenakan oleh sebagian orang yang merasa sudah nyaman dengan apa yang selama ini dilakukan, sehingga jika dilakukan perubahan atas kebiasaan tersebut maka akan muncul keengganan untuk berubah. Resistensi ini juga terjadi di Pusdiklat Anggaran dan Perbendaharaan, khususnya bagi mereka yang tidak mengikuti perkembangan teknologi. Padahal kemajuan teknologi menuntut perubahan metode kerja dari yang semula konvensional, masih manual dan lebih banyak pekerjaan klerikal menjadi metode kerja berbasis sistem. Kemajuan teknologi menuntut dinamika kerja yang lebih kreatif dan inovatif, termasuk juga dalam pengelolaan diklat terlebih diklat berbasis e-learning. Perkembangan teknologi juga memberikan berbagai fasilitas yang dapat dimanfaatkan di bidang kediklatan, khususnya terkait dengan konten pembelajaran. Semakin mudahnya akses berbagai informasi dengan berbagai macam bentuk (multimedia) tersedia di dunia maya. Namun jika resistensi terhadap kemajuan teknologi ini masih ada, maka sikap ini akan menjadi penghambat kemajuan organisasi.

3. Bahan ajar interaktif masih sangat kurang.

Penyelenggaraan diklat berbasis $e$ learning dituntut untuk dapat menyediakan bahan ajar sesuai dengan kebutuhan pembelajaran. Upaya yang dilakukan dapat berupa mengalihmediakan materi ke dalam bentuk multimedia. Sebagaimana disampaikan oleh Palupi (2012), konten e-learning pada Diklat Teknis Pengelolaan Perpustakaan telah mengalihmediakan seluruh materi menjadi bentuk multimedia, yaitu: teks dengan format pdf, video dengan format flv, presentasi dengan format flash player, audio dengan format MP3, dan presentasi instruktur dengan MS power point.

Kondisi yang ada pada Pusdiklat Anggaran dan Perbendaharaan, bahan ajar yang tersedia masih sebatas modul dan bahan tayang berupa power point. Hal ini dapat difahami mengingat untuk dapat membuat modul $e$ learning dengan content dan packaging yang baik memerlukan keahlian khusus serta tenaga dan waktu yang tidak sedikit. Untuk keperluan itu perlunya ada satu institusi yang secara khusus bertanggung jawab untuk membantu dosen dalam menyiapkan content dan packaging materi-materi kuliah. Selanjutnya untuk dapat membuat modul e-learning yang baik maka pengetahuan dosen yang terkait dengan pedagogik dan aktivitas intruksional harus diberikan terlebih dahulu. Pengetahuan ini akan menjadi modal berharga dalam menyusun materi-materi yang akan dikemas dalam paket e-learning (Prayudi 2009). Saat observasi lapangan mendapatkan informasi bahwa secara simultan untuk kelengkapan bahan ajar akan sambil dilakukan penambahan dan perbaikan. Hal ini dilihat sebagai kekurangsiapan penyelenggara diklat.

4. Penugasan terhadap Widyaiswara masih mengalami tumpang tindih.

Widyaiswara adalah jabatan
fungsional dalam lingkup PNS di
Indonesia. Widyaiswara bekerja
hampir sama dengan trainer atau
fasilitator. Tugasnya adalah mendidik
dan melatih PNS agar mampu bekerja
dengan baik di bagian masing-masing
(Sugandi 2016). Dengan keahlian yang 
dimiliki berdasarkan rumpun keilmuannya, sering Widyaiswara diperlukan sebagai narasumber dalam berbagai kegiatan, tidak hanya di dalam institusinya bahkan sering juga diluar institusi. Kadangkala penugasan atau permintaan datang dari pimpinan yang lebih tinggi dan sifatnya wajib, misalnya dari pejabat eselon I atau menteri. Hal seperti ini menjadi penyebab Widyaiswara mendapat tugas ganda pada saat bersamaan, dan harus memilih prioritas sehingga ada yang terpaksa harus dikorbankan. Dan ketika mengajar yang harus dikalahkan, maka hal ini dapat mengganggu proses pembelajaran.

Banyaknya diklat yang diselenggarakan juga mengakibatkan sebagian besar waktu Widyaiswara digunakan untuk mengajar, sehingga waktu yang digunakan untuk penyiapan proses pembelajaran diklat menjadi berkurang. Dengan waktu yang sempit maka dalam mempersiapkan materi belajar, menyusun modul, menyiapkan bahan tayang, membuat materi dalam bentuk multimedia menjadi kurang memperoleh bagian.

5. Jumlah karya ilmiah dan penelitian masih sangat terbatas.

Karya ilmiah dan penelitian tersebut memiliki peranan besar dalam mengembangkan kompetensi keahlian yang bersifat spesialis dan membangun reputasi kepakaran Widyaiswara dan reputasi institusi kediklatan. Dengan mengaplikasikan metodologi riset dalam upaya memperoleh temuan dalam bidang pendidikan, berbagai temuan yang dihasilkan selain dapat dipertanggungjawabkan secara akademik dan saintifik juga memberikan kontribusi terhadap pengembangan keilmuan dan praktik penyelenggaraan pendidikan. Peningkatan keilmuwan melalui kegiatan penelitian harusnya dapat dimanfaatkan untuk membangun konten belajar yang baik.

Sebagaimana tertuang dalam Renstra BPPK 2015-2019, kelemahan yang sekaligus menjadi tantangan yaitu Widyaiswara lebih berfokus pada kegiatan mengajar, sehingga jumlah publikasi karya ilmiah dan penelitian masih terbatas. Disamping juga belum adanya pengelolaan penelitian dan pengembangan (litbang) yang terarah dan mendukung pengembangan kompetensi teknis Widyaiswara dalam bidang keilmuan yang diampu.

\section{Peluang (Opprtunities)}

1. Rekomendasi hasil kajian terkait $e$ learning di Pusdiklat Anggaran dan Perbendaharaan.

Hasil kajian terhadap kinerja organisasi dapat dipergunakan untuk evaluasi, meskipun kajian tersebut dilakukan oleh pihak luar. Terdapat satu kajian terkait e-learning di Pusdiklat Anggaran dan Perbendaharaan yang menyatakan bahwa diklat berbasis e-learning tidak lebih efektif dibandingkan dengan diklat klasikal. Hal tersebut disebabkan oleh permasalahan penyiapan konten, yaitu tidak tepatnya penggunaan metode dalam menyampaikan materi. Akibatnya adalah peserta menjadi tidak dapat memahami materi yang diberikan. Untuk materi yang membutuhkan praktek/simulasi, bahan ajar yang tepat misalnya menggunakan animasi, audio maupun video. Namun hal ini belum dilakukan oleh penyelenggara diklat. Oleh karena itu peneliti merekomendasikan supaya bahan ajar disusun menyesuaikan dengan kebutuhan dan tujuan pembelajaran (Munajatisari 2014).

2. Tersedia berbagai program pelatihan/shortcourse yang diselenggarakan oleh pihak luar. 
Banyak lembaga pelatihan baik dari dalam maupun luar negeri yang memberikan tawaran program dalam bentuk seminar, workshop, shortcourse, dan sejenisnya. Hal ini menjadi peluang baik untuk menambah ilmu, wawasan, dan pengetahuan bagi para pegawai Pusdiklat Anggaran dan Perbendaharaan. Pengiriman pegawai untuk mengikuti pelatihan disesuaikan dengan latar belakang keilmuan yang dimiliki, sehingga tujuan mereka mengikuti pelatihan adalah mempertajam bidang ilmu yang dikuasai. Investasi dalam ilmu pengetahuan akan menambah kekayaan referensi/perbendaharaan materi yang berguna untuk mendukung proses pembelajaran dalam diklat.

3. Perkembangan yang pesat bidang Teknologi Informasi dan Komunikasi serta ilmu pengetahuan.

Tidak dapat dielakkan bahwa teknologi saat ini telah berkembang dengan pesat. Kemajuan teknologi yang ada saat ini mempunyai peluang yang sangat besar untuk dimanfaatkan dalam proses pembelajaran. Berbagai kemudahan diberikan kepada pengguna teknologi, efisiensi waktu dan biaya juga dirasakan dengan adanya teknologi, termasuk teknologi informasi dan komunikasi. Diklat dengan metode e-learning adalah bagian dari pemanfaatan teknologi. Untuk itu dengan kemajuan teknologi, hendaknya sistem pembelajaran yang dibangun harus lebih user friendly.

4. Ketersediaan layanan pengembangan LMS dan QC dari Sekretariat BPPK maupun Setjen Kementerian Keuangan.

Pusat Sistem Informasi dan Teknologi Keuangan (Pusintek) sebagai pengelola IT di lingkungan Kementerian Keuangan mempunyai tugas diantaranya adalah melakukan fungsi layanan TIK tidak hanya untuk unitnya namun juga kepada semua unit di lingkup Kementerian Keuangan. Pengembangan LMS di BPPK dilakukan oleh Sekretariat, sedangkan quality control dilaksanakan oleh Pusintek. Melalui sinergi yang baik ini menjadi peluang bagi Pusdiklat Anggaran dan Perbendaharaan untuk meningkatkan kualitas layanan $e$ learning, khususnya layanan dalam sistem aplikasi pembelajaran.

5. Potential trainee sangat banyak untuk program diklat terkait pengelolaan keuangan negara.

Terdapat sekitar 24.000 satker di seluruh wilayah Indonesia ini yang membutuhkan kompetensi di bidang pengelolaan keuangan negara. Untuk menjangkau mereka tidak mungkin dilakukan secara klasikal. Akan lebih efektif dan efisien jika dibantu dengan e-learning. Potential trainee yang sangat besar ini menjadi peluang bagi Pusdiklat Anggaran dan Perbendaharaan untuk memberikan program-program berkualitas yang mampu memenuhi kebutuhan mereka.

D. Ancaman (Threats)

1. Kebijakan Lembaga Administrasi Negara (LAN) belum sepenuhnya mengakomodir angka kredit bagi Widyaiswara yang melaksanakan aktivitas pembelajaran berbasis $e$ learning.

Sebagai pusat pembinaan Widyaiswara, LAN memiliki tugas diantaranya merumuskan kebijakan untuk jabatan fungsional Widyaiswara termasuk kebijakan penetapan angka kredit. Kenaikan golongan atau kenaikan jabatan Widyaiswara dihitung berdasarkan perolehan angka kredit. Maka, berbagai pengembangan kegiatan diklat yang sudah tentu melibatkan peran besar Widyaiswara sudah selayaknya dapat diakomodir untuk perhitungan angka kredit. 
Kekhawatiran yang muncul apabila kegiatan terkait e-learning tidak diakomodir, Widyaiswara tidak memiliki interes untuk mengerjakan kegiatan e-learning tetapi lebih memilih kegiatan yang menghasilkan angka kredit. Padahal Widyaiswara adalah aktor utama dalam proses pembelajaran baik klasikal maupun $e$ learning.

2. Pelaksanaan Identifikasi Kebutuhan Diklat (IKD) masih tergantung pada unit teknis.

Tujuan dilakukannya IKD adalah untuk mengidentifikasi kesenjangan antara tingkat kompetensi yang diharapkan unit pengguna dengan tingkat kompetensi yang dimiliki oleh PNS dan CPNS. IKD sekaligus sebagai alat untuk memperoleh informasi mengenai kesenjangan kompetensi yang meliputi pengetahuan, keahlian, dan sikap yang perlu dipenuhi melalui diklat. Hasil dari IKD akan ditindaklanjuti dengan desain program.

Dalam Peraturan Menteri Keuangan nomor 37/PMK.12/2014 tentang Pedoman Identifikasi Kebutuhan Pendidikan dan Pelatihan Non Gelar di Lingkungan Kementerian Keuangan, yang melakukan IKD adalah unit teknis atau unit pengguna. Hal ini menyebabkan ketergantungan unit pengelola diklat pada unit pengguna atau unit teknis yang melakukan IKD. Kekhawatiran yang muncul apabila ketidaktepatan dalam proses IKD, maka akan berdampak pada ketidaktepatan penyiapan program diklat termasuk ketidaktepatan penyiapan konten belajarnya.

3. Ketergantungan tenaga ahli/praktisi dari unit teknis.

Sebagaimana tertuang dalam Renstra BPPK bahwa terdapat kesenjangan antara kebutuhan pengetahuan/kompetensi khususnya terkait dengan hal teknis terkini yang diharapkan dari unit pengguna diklat dengan pengetahuan/kompetensi yang dimiliki Widyaiswara di BPPK. Untuk memenuhi kompetensi tertentu yang tidak tersedia dari BPPK, maka yang dilakukan adalah mengundang narasumber yang kompeten, dan biasanya adalah tenaga ahli/praktisi berasal dari unit teknis. Dalam kondisi tertentu kompetensi mereka dibutuhkan tidak hanya pada saat diklat sedang berlangsung, namun tidak jarang mereka turut terlibat sejak merumuskan desain program diklat termasuk konten diklat. Ketergantungan dengan pihak luar tentunya akan menjadi ancaman bagi keberlangsungan proses diklat.

4. Keterbatasan dalam akses LMS.

Diklat berbasis e-learning yang dikembangkan BPPK dapat diakses melalui internet. Untuk itu ketersediaan jaringan menjadi syarat mengakses LMS. Kestabilan dan ketersediaan jaringan sangat tergantung oleh pihak luar, dalam hal ini penyediaan kapasitas dilakukan melalui persetujuan Pusintek. Dalam membangun LMS atau pengembangannya dan pada saat dilakukan QC sangat dibutuhkan ketersediaan jaringan untuk mengakses LMS.

Untuk saat ini LMS baru dapat diakses menggunakan personal computer (PC) atau laptop, belum dapat diakses misalnya melalui smartphone. Sementara dengan semakin berkembangnya teknologi sangat memungkinkan aplikasi ini tersedia dalam versi android. Pengguna layanan juga akan merasa dimudahkan dan didekatkan jika tersedia dalam versi android.

5. Adanya resistensi peserta diklat terhadap perubahan metode diklat.

Zona nyaman dapat membuat seseorang resisten terhadap perubahan. Demikian halnya dengan adanya 
perubahan metode diklat dari yang sepenuhnya klasikal menjadi blended learning, dimana metode blended learning menghendaki peserta diklat mampu belajar secara mandiri dan kendalinya ada pada peserta. Untuk keperluan evaluasi guna memberikan saran dan masukan penyediaan layanan e-learning, evaluator harus berinteraksi dengan perangkat $e$ learning. Evaluator yang memiliki resistensi dengan perubahan metode diklat mungkin tidak akan memberikan masukan atau saran. Hal ini menjadi sebuah tantangan bagi
Pusdiklat Anggaran dan Perbendaharaan bagaimana agar peserta dapat berpartisipasi aktif dalam belajar mandiri tersebut dan memberikan evaluasi yang tepat serta memberikan saran perbaikan.

Seluruh faktor tersebut selanjutnya dituangkan dalam kuesioner untuk diberikan bobot dan peringkat (rating) oleh responden. Analisis dilakukan menggunakan Matriks IFE dan EFE. Tabel 1 menunjukkan hasil penilaian terhadap faktor-faktor internal.

Tabel 1 Hasil Penilaian Responden Terhadap Faktor-Faktor Internal

\begin{tabular}{|c|c|c|c|c|}
\hline No & $\begin{array}{l}\text { Faktor Srategis Internal } \\
\end{array}$ & Bobot & Rating & Skor \\
\hline & Kekuatan (Strengths) & & & \\
\hline 1 & Desain program diklat telah melalui proses validasi & 0,137 & 3,60 & 0,492 \\
\hline 2 & $\begin{array}{l}\text { Ketersediaan tenaga pengajar yang kompeten dengan } \\
\text { dibuktikan melalui sertifikasi }\end{array}$ & 0,114 & 3,40 & 0,389 \\
\hline 3 & SDM pengelola diklat yang berkualitas & 0,097 & 3,20 & 0,309 \\
\hline 4 & $\begin{array}{l}\text { Sarana dan prasarana yang mendukung penyelenggaraan } \\
\text { diklat }\end{array}$ & 0,099 & 3,60 & 0,356 \\
\hline \multirow[t]{3}{*}{5} & $\begin{array}{l}\text { Koordinasi yang baik dengan unit teknis selaku perancang } \\
\text { kebijakan }\end{array}$ & 0,103 & 3,40 & 0,351 \\
\hline & \multicolumn{3}{|l|}{ 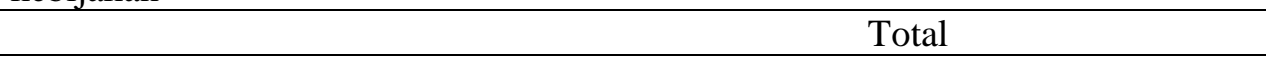 } & 1,898 \\
\hline & \multicolumn{4}{|l|}{ Kelemahan (Weaknesses) } \\
\hline 1 & $\begin{array}{l}\text { Penyelenggaraan diklat dengan metode } e \text {-learning belum } \\
\text { memperoleh quality assurance dari lembaga sertifikasi }\end{array}$ & 0,064 & 1,80 & 0,116 \\
\hline 2 & Adanya pegawai yang resisten terhadap perubahan & 0,071 & 1,40 & 0,100 \\
\hline 3 & Bahan ajar interaktif masih sangat kurang & 0,119 & 2,00 & $\mathbf{0 , 2 3 8}$ \\
\hline 4 & $\begin{array}{l}\text { Penugasan terhadap Widyaiswara masih mengalami } \\
\text { tumpang tindih }\end{array}$ & 0,091 & 1,40 & 0,128 \\
\hline 5 & Jumlah karya ilmiah dan penelitian masih sangat terbatas & 0,104 & 1,60 & 0,167 \\
\hline \multicolumn{4}{|c|}{ Total } & 0,748 \\
\hline \multicolumn{4}{|c|}{ TOTAL IFE } & 2,646 \\
\hline
\end{tabular}

Total skor IFE diatas 2,5 mengindikasikan bahwa organisasi memiliki posisi internal yang kuat. Hal ini menunjukkan Pusdiklat Anggaran dan Perbendaharaan memiliki kekuatan internal untuk meningkatkan kualitas konten diklat berbasis e-learning. Faktor yang dianggap sebagai kekuatan utama yaitu desain program diklat yang telah melalui proses validasi guna memastikan program tersebut layak untuk diselenggarakan. Faktor yang dianggap sebagai kelemahan utama adalah bahan ajar interaktif masih sangat kurang.

Total skor EFE sebagaimana dapat dilihat pada Tabel 2 menunjukkan hasil lebih besar dari 2,5. Hal tersebut berarti bahwa Pusdiklat Anggaran dan Perbendaharaan merespon dengan baik terhadap peluang dan ancaman yang ada. 
Tabel 2 Hasil Penilaian Responden Terhadap Faktor-Faktor Eksternal

\begin{tabular}{|c|c|c|c|c|}
\hline No & Faktor Srategis Eksternal & Bobot & Rating & Skor \\
\hline & Peluang (Opportunities) & & & \\
\hline 1 & $\begin{array}{l}\text { Rekomendasi hasil kajian terkait e-learning di Pusdiklat } \\
\text { Anggaran dan Perbendaharaan }\end{array}$ & 0,097 & 2,60 & 0,251 \\
\hline 2 & $\begin{array}{l}\text { Tersedia berbagai program pelatihan/ shortcourse yang } \\
\text { diselenggarakan oleh pihak luar }\end{array}$ & 0,134 & 3,00 & $\mathbf{0 , 4 0 3}$ \\
\hline 3 & $\begin{array}{l}\text { Perkembangan yang pesat bidang Teknologi Informasi } \\
\text { dan Komunikasi serta ilmu pengetahuan }\end{array}$ & 0,111 & 2,80 & 0,311 \\
\hline 4 & $\begin{array}{l}\text { Ketersediaan layanan pengembangan LMS dan QC dari } \\
\text { Sekretariat BPPK maupun Setjen Kementerian Keuangan }\end{array}$ & 0,088 & 2,40 & 0,211 \\
\hline 5 & $\begin{array}{l}\text { Potential trainee sangat banyak untuk program diklat } \\
\text { terkait pengelolaan keuangan negara }\end{array}$ & 0,116 & 2,40 & 0,277 \\
\hline \multicolumn{4}{|c|}{ Total } & 1,454 \\
\hline \multirow[b]{2}{*}{1} & n (Threats) & & & \\
\hline & $\begin{array}{l}\text { Kebijakan Lembaga Administrasi Negara (LAN) belum } \\
\text { sepenuhnya mengakomodir angka kredit bagi } \\
\text { Widyaiswara yang melaksanakan aktivitas pembelajaran } \\
\text { berbasis } e \text {-learning }\end{array}$ & 0,107 & 3,00 & 0,320 \\
\hline 2 & Pelaksanaan IKD masih tergantung pada unit teknis & 0,106 & 2,80 & 0,296 \\
\hline 3 & Ketergantungan tenaga ahli/praktisi dari unit teknis & 0,126 & 3,00 & $\mathbf{0 , 3 7 7}$ \\
\hline 4 & Keterbatasan dalam akses LMS & 0,061 & 2,40 & 0,147 \\
\hline 5 & Adanya resistensi terhadap perubahan metode diklat & 0,056 & 2,60 & 0,144 \\
\hline \multicolumn{4}{|c|}{ Total } & 1,283 \\
\hline & TOTAL EFE & & & 2,737 \\
\hline
\end{tabular}

Peluang dengan nilai skor tertimbang paling besar yaitu tersedianya berbagai program pelatihan/shortcourse yang diselenggarakan oleh pihak luar. Peluang ini dimanfaatkan untuk meningkatkan kapasitas para pegawai pusdiklat dengan mengirimkan pegawainya untuk mengikuti pelatihan sesuai dengan kebutuhan. Faktor utama yang dianggap menjadi ancaman yaitu adanya ketergantungan tenaga ahli/praktisi yang berasal dari unit teknis. Dalam kondisi tertentu, ketika tenaga ahli tidak dapat dipenuhi dari internal pusdiklat, maka yang dilakukan adalah mendatangkan tenaga ahli/praktisi dari luar. Hal yang demikian ini tentunya menimbulkan ketergantungan kepada pihak lain, dimana ketergantungan tersebut tidak dapat dikendalikan oleh Pusdiklat Anggaran dan Perbendaharaan.
Hal ini menyebabkan pusdiklat tidak memiliki bargaining position. Apabila kondisi yang demikian dibiarkan terusmenerus, maka ancaman terhadap keberlangsungan proses pembelajaran (diklat) dapat terganggu.

\section{Perumusan Strategi Peningkatan Kualitas Konten Diklat Berbasis $E$ - Learning}

Perumusan strategi dilakukan dengan menuangkan faktor-faktor internal dan eksternal ini dalam matriks SWOT. Analisis SWOT sebagaimana Tabel 3 digunakan untuk merumuskan strategi dengan menggabungkan kekuatan dengan peluang, kelemahan dengan peluang, kekuatan dengan ancaman, dan kelemahan dengan ancaman. 


\begin{tabular}{|c|c|c|}
\hline Faktor & Kekuatan/Strengths $(\mathbf{S})$ & Kelemahan/Weaknesses (W) \\
\hline Eksternal & $\begin{array}{l}\text { 2. Tenaga pengajar yang } \\
\text { kompeten } \\
\text { 3. SDM pengelola diklat } \\
\text { yang berkualitas } \\
\text { 4. Sarana dan prasarana } \\
\text { yang mendukung } \\
\text { penyelenggaraan diklat } \\
\text { 5. Koordinasi yang baik } \\
\text { dengan unit teknis } \\
\text { selaku perancang }\end{array}$ & $\begin{array}{l}\text { 1. Diklat metode } \text { e-learning } \\
\text { belum memperoleh quality } \\
\text { assurance dari lembaga } \\
\text { sertifikasi } \\
\text { 2. Resistensi terhadap } \\
\text { perubahan } \\
\text { 3. Bahan ajar interaktif masih } \\
\text { sangat kurang } \\
\text { 4. Penugasan terhadap } \\
\text { Widyaiswara masih } \\
\text { mengalami tumpang tindih } \\
\text { 5. Jumlah karya ilmiah dan } \\
\text { penelitian masih sangat } \\
\text { terbatas }\end{array}$ \\
\hline
\end{tabular}

\begin{tabular}{|c|c|c|}
\hline Peluang/Opportunities $(\mathrm{O})$ & Strategi S-O & Strategi W-O \\
\hline $\begin{array}{l}\text { 1.Rekomendasi kajian e-learning di } \\
\text { Pusdiklat Anggaran dan } \\
\text { Perbendaharaan } \\
\text { 2.Program pelatihan/ shortcourse } \\
\text { yang diselenggarakan pihak luar } \\
\text { 3. Perkembangan Teknologi } \\
\text { Informasi dan Komunikasi serta } \\
\text { ilmu pengetahuan } \\
\text { 4.Ketersediaan layanan } \\
\text { pengembangan LMS dan QC dari } \\
\text { Sekretariat BPPK maupun Setjen } \\
\text { Kementerian Keuangan } \\
\text { 5.Potential trainee sangat banyak } \\
\text { untuk program diklat terkait } \\
\text { pengelolaan keuangan negara }\end{array}$ & $\begin{array}{l}\text { 1. Optimalisasi layanan } \\
\text { kediklatan dengan } \\
\text { membangun layanan } \\
\text { unggulan diklat } \\
\text { berbasis e-learning } \\
\text { (S1, S2, S3, S4, S5, } \\
\mathrm{O} 1, \mathrm{O} 2, \mathrm{O} 3, \mathrm{O} 4, \mathrm{O} 5)\end{array}$ & $\begin{array}{ll}\text { 2. } & \text { Penyempurnaan } \\
\text { pengelolaan diklat } \\
\text { berbasis e-learning } \\
\text { melalui penataan proses } \\
\text { bisnis }(\mathrm{W} 1, \mathrm{~W} 2, \mathrm{~W} 3, \\
\mathrm{W} 4, \mathrm{~W} 5, \mathrm{O} 1, \mathrm{O} 3, \mathrm{O} 4)\end{array}$ \\
\hline Ancaman/Threats $(\mathrm{T})$ & $\begin{array}{l}\text { Strategi S-T } \\
\end{array}$ & $\begin{array}{c}\text { Strategi W-T } \\
\end{array}$ \\
\hline $\begin{array}{l}\text { 1. Kebijakan LAN belum sepenuhnya } \\
\text { mengakomodir aktivitas } \\
\text { pembelajaran berbasis } e \text {-learning } \\
\text { 2.Pelaksanaan IKD tergantung pada } \\
\text { unit teknis } \\
\text { 3.Dukungan tenaga ahli/praktisi dari } \\
\text { unit teknis } \\
\text { 4. Keterbatasan dalam akses LMS } \\
\text { 5.Adanya resistensi terhadap } \\
\text { perubahan metode diklat }\end{array}$ & $\begin{array}{l}\text { 3. Penguatan kebijakan } \\
\text { dan regulasi yang } \\
\text { mendorong } \\
\text { implementasi } e- \\
\text { learning }(\mathrm{S} 2, \mathrm{~S} 3, \mathrm{~S} 5 \text {, } \\
\mathrm{T} 1, \mathrm{~T} 2, \mathrm{~T} 3)\end{array}$ & $\begin{array}{l}\text { 4. } \\
\text { Penguatan peran } \\
\text { Widyaiswara dalam } \\
\text { membangun diklat } \\
\text { berbasis e-learning } \\
\text { sebagai program prioritas } \\
\text { unggulan (W3, W4, W5, } \\
\text { T2, T3, T4, T5) }\end{array}$ \\
\hline
\end{tabular}

Hasil analisis SWOT merumuskan empat alternatif strategi, yaitu:

1. Optimalisasi layanan kediklatan dengan membangun layanan unggulan diklat berbasis e-learning.

2. Penyempurnaan pengelolaan diklat berbasis e-learning melalui penataan proses bisnis.
3. Penguatan kebijakan dan regulasi yang mendorong implementasi e-learning .

4. Penguatan peran Widyaiswara dalam membangun diklat berbasis e-learning sebagai program prioritas unggulan.

Untuk menentukan strategi prioritas dilakukan dengan menetapkan tingkat daya tarik relatif (relative attractiveness) dari keempat alternatif strategi 
menggunakan Attractive Score (AS). QSPM adalah alat yang memungkinkan para penyusun strategi mengevaluasi berbagai strategi alternatif secara objektif (David 2012). Analisis QSPM akan menghitung besaran Total Attractive
Score (TAS) pada masing-masing alternatif strategi. Nilai TAS tertinggi merupakan strategi prioritas. Tabel 4 menunjukkan hasil penilaian TAS pada QSPM

Tabel 4 Hasil penilaian Total Attractiveness Score (TAS) menggunakan QSPM

\begin{tabular}{clc}
\hline No & \multicolumn{1}{c}{ Strategi } & TAS \\
\hline 1. & $\begin{array}{l}\text { Optimalisasi layanan kediklatan dengan membangun layanan unggulan diklat } \\
\text { berbasis e-learning. }\end{array}$ & 7,201 \\
2. & $\begin{array}{l}\text { Penyempurnaan pengelolaan diklat berbasis } \\
\text { proses bisnis. }\end{array}$ & 6,867 \\
3. & $\begin{array}{l}\text { Penguatan kebijakan dan regulasi yang mendorong implementasi e-learning. } \\
\text { 4. }\end{array}$ & $\begin{array}{l}\text { Penguatan peran Widyaiswara dalam membangun diklat berbasis } \text { e-learning } \\
\text { sebagai program prioritas unggulan. }\end{array}$ \\
\hline
\end{tabular}

Dengan demikian strategi prioritas yang diperoleh dari penelitian ini yaitu optimalisasi layanan kediklatan dengan membangun layanan unggulan diklat berbasis e-learning. Dengan ditetapkannya diklat berbasis e-learning menjadi layanan unggulan maka seluruh sumber daya akan difokuskan untuk menjadikan e-learning sebagai program prioritas atau program unggulan. Strategi prioritas pertama merupakan strategi yang direkomendasikan untuk dilakukan oleh Pusdiklat Anggaran dan Perbendaharaan, sedangkan ketiga strategi lainya dapat diupayakan untuk dilaksanakan diselaraskan dengan strategi prioritas yang ditentukan oleh pengambil kebijakan. Strategi yang mendukung atau mempunyai hubungan timbal balik dengan strategi prioritas dapat pula dilaksanakan secara paralel untuk mendukung pencapaian strategi prioritas. Untuk dapat mengimplementasikan strategi prioritas maka perlu disusun rumusan strategi ke dalam pelaksanaan kebijakan operasional dalam bentuk program dan kegiatan yang lebih rinci sebagaimana dapat dilihat pada Tabel 5.

Tabel 5 Perancangan strategi, kebijakan, program dan kegiatan

\begin{tabular}{|c|c|c|c|}
\hline Strategi & Kebijakan & Program & Kegiatan \\
\hline $\begin{array}{l}\text { Optimalisasi } \\
\text { layanan } \\
\text { kediklatan } \\
\text { dengan } \\
\text { membangun } \\
\text { layanan } \\
\text { unggulan diklat } \\
\text { berbasis } e- \\
\text { learning }\end{array}$ & $\begin{array}{l}\text { Penyediaan } \\
\text { materi belajar } \\
\text { dalam } \\
\text { kemasan yang } \\
\text { menarik, } \\
\text { memenuhi } \\
\text { kebutuhan } \\
\text { pengguna dan } \\
\text { user friendly }\end{array}$ & $\begin{array}{l}\text { 2. Merancang } \\
\text { materi belajar } \\
\text { dalam bentuk } \\
\text { micro } \\
\text { learning }\end{array}$ & $\begin{array}{l}\text { 1. Menetapkan tema belajar, } \\
\text { 2. Marasumber, moderator/host } \\
\text { 2. Menyusun skrip/naskah } \\
\text { 3. Pengambilan gambar/ shooting } \\
\text { 4. Menyunting/Edit } \\
\text { 5. Quality Control } \\
\text { 1. Mem-breakdown materi diklat } \\
\text { dalam kelompok tema yang } \\
\text { lebih kecil } \\
\text { 2. Menentukan metode delivery } \\
\text { 3. Menyusun materi } \\
\text { 4. Pengesahan } \\
\text { 1. Pemilihan materi belajar } \\
\text { 2. Membuat use case diagnosa } \\
\text { 3. } \text { aplikasi } \\
\text { 4. Quality Assurance }\end{array}$ \\
\hline
\end{tabular}




\section{SIMPULAN DAN SARAN}

\section{Simpulan}

Berdasarkan hasil analisis yang dilakukan pada penelitian ini, dapat disimpulkan beberapa hal sebagai berikut:

1. Hasil analisis IFE menunjukkan bahwa faktor kekuatan utama adalah desain program diklat yang telah melalui proses validasi, sedangkan faktor kelemahan utama yaitu bahan ajar interaktif yang masih sangat kurang. Hasil analisis EFE menunjukkan bahwa faktor peluang utama adalah tersedia berbagai program pelatihan/shortcourse yang diselenggarakan oleh pihak luar, dan faktor ancaman utama yaitu ketergantungan tenaga ahli/praktisi dari unit teknis.

2. Strategi prioritas yang dapat dilakukan oleh Pusdiklat Anggaran dan Perbendaharaan untuk meningkatkan kualitas konten diklat berbasis e-learning adalah optimalisasi layanan kediklatan dengan membangun layanan unggulan diklat berbasis e-learning. Guna menjadikan e-learning sebagai produk unggulan, maka kebijakan yang ditetapkan yaitu penyediaan materi belajar dalam kemasan yang menarik, memenuhi kebutuhan pengguna dan user friendly. Kebijakan ini dijabarkan dalam tiga program yaitu merancang program edutainment, merancang materi belajar dalam bentuk micro learning, dan menyediakan aplikasi LMS versi android.

\section{Saran}

1. Meningkatkan kualitas layanan diklat dengan menjadikan e-learning sebagai layanan unggulan pada Pusdiklat Anggaran dan Perbendaharaan.
2. Strategi yang dirumuskan akan lebih optimal jika dieskalasi pada level yang lebih tinggi, yaitu oleh BPPK. Dengan demikian diharapkan seluruh unit diklat di bawah BPPK memiliki standar pelayanan yang sama.

\section{DAFTAR PUSTAKA}

Anggraini NI. 2014. Manajemen Mutu Pembelajaran di SMP Negeri 115 Jakarta. Jurnal Improvement. Vol 1, Edisi 1.

[BPPK] Badan Pendidikan dan Pelatihan Keuangan. 2011. Keputusan Kepala Badan Pendidikan dan Pelatihan Keuangan Nomor KEP006.1/PP/2011 tentang Validasi Program Diklat.

[BPPK] Badan Pendidikan dan Pelatihan Keuangan. 2011. Keputusan Kepala Badan Pendidikan dan Pelatihan Keuangan Nomor KEP007.1/PP/2011 tentang Standar Sarana dan Prasarana di Lingkungan BPPK.

[BPPK] Badan Pendidikan dan Pelatihan Keuangan. 2015. Keputusan Kepala Badan Pendidikan dan Pelatihan Keuangan Nomor KEP1162/PP/2015 tentang Rencana Strategis Badan Pendidikan dan Pelatihan Keuangan Tahun 20152019.

David FR. 2012. Strategic Management Manajemen Strategis Konsep. Sunardi D, Penerjemah; Wuriarti P, editor. Jakarta (ID): Salemba Empat. Terjemahan dari: Strategic Management, $12^{\text {th }}$ ed.

David FR, David FR. 2016. Manajemen Strategik Suatu Pendekatan Keunggulan Bersaing. Puspasari N, Puspitasari LN, Penerjemah; Halim DA, editor. Jakarta (ID): Salemba Empat. Terjemahan dari: Strategic Management: A Competitive Advantage Approach, Concepts and Cases, 15th ed.

Hernawati E, Aji P. 2016. Perancangan dan Penerapan Konten E- 
Learning melalui Learning Management System dalam Meningkatkan Motivasi Belajar Studi Kasus pada Mata Kuliah Pemrograman Basis Data. Journal of Information Systems Engineering and Business Intelligence. Vol. (2); No. 1.

[KEMENKEU] Kementerian Keuangan Republik Indonesia. Peraturan Menteri Keuangan nomor 37/PMK.12/2014 tentang Pedoman Identifikasi Kebutuhan Pendidikan dan Pelatihan Non Gelar di Lingkungan Kementerian Keuangan.

Munajatisari RR. 2014. Analisis Efektivitas Metode Pelatihan Klasikal dan E-Learning. Jurnal Administrasi Bisnis. Vol. 10 no. 2. hal 173-185.

Oketch HA, Njihia JM, Wausi AN. 2014. E-Learning

Readiness
Assessment Model in Kenyas' Higher Education Institutions: a Case Study of University of Nairobi. International Journal of Scientific Knowledge. Vol. (5); No. 6.

Palupi S. 2012. Analisis dan Desain ELearning Diklat Teknis Pengelolaan Perpustakaan menggunakan Standar Learning Technology System Architecture (IEEE P1484.1). Tesis. Bogor (ID): Institut Pertanian Bogor.

Prayudi Y. 2009. Kajian Awal: ELearning Readiness Index (ELRI) sebagai Model bagi Evaluasi ELearning pada Sebuah Institusi. Seminar Nasional Aplikasi Teknologi Informasi (SNATI).

Sugandi. 2016. Selayang Pandang Profesi Widyaiswara. Jogjakarta (ID): Garudhawaca. 